\title{
First report of multiple anthelmintic resistance in nematodes of sheep in Colombia
}

\author{
CARLOS M.B. GÁRCIA ${ }^{1}$, LEW K. SPRENGER ${ }^{2}$, EFRAÍN B. ORTIZ ${ }^{1}$ and MARCELO B. MOLENTO ${ }^{2,3}$ \\ ${ }^{1}$ College of Agricultural Sciences, University of La Salle, Cra. 5 No. 59A-44, Bogota, Colombia. \\ ${ }^{2}$ Laboratório de Doenças Parasitárias, Departamento de Medicina Veterinária, Universidade Federal \\ do Paraná/UFPR, Rua dos Funcionários, 1540, 80035-050 Curitiba, PR, Brasil \\ ${ }^{3}$ Instituto National de Ciência e Tecnologia/INCT/Pecuária, Avenida Antonio \\ Carlos, 6627, 31270-901 Belo Horizonte, MG, Brasil
}

Manuscript received on July 22, 2014; accepted for publication on May 28, 2015

\begin{abstract}
This study aimed to report the presence of parasites resistant to the most used anthelmintic drugs in sheep in Colombia. Four farms (denominated farm 1, 2, 3 and 4) were selected where the animals were not treated with anthelmintics for two months before the trial. Animals with faecal egg count (FEC) above 150 and of different ages were allocated into six groups, each consisting of at least 5 animals. The drugs and dosages used were: ivermectin $1 \%(0.2 \mathrm{mg} / \mathrm{kg})$, albendazole $25 \%(5 \mathrm{mg} / \mathrm{kg})$, fenbendazole $10 \%(5 \mathrm{mg} / \mathrm{kg})$, levamisole $10 \%(5 \mathrm{mg} / \mathrm{kg})$, and moxidectin $1 \%(0.2 \mathrm{mg} / \mathrm{kg})$. Anthelmintic efficacy was determined by the FEC reduction test (FECRT) with a second sampling 14 days post-treatment. The efficacy of albendazole and fenbendazole at farm 1 was above $95 \%$, which was different from the others farms. The FECRT indicated the presence of multidrug resistance in the other farms where no tested drugs showed activity higher than $79 \%$ (albendazole: 0 to $55 \%$, fenbendazole: 51.4 to $76.6 \%$, ivermectin: 67.3 to $93.1 \%$, levamisole: 0 to $78.1 \%$, and moxidectin: 49.2 to $64.1 \%$ ). Haemonchus contortus was the predominant (96\%) species, followed by a small presence of Trichostrongylus sp. (3\%) and Cooperia sp. (1\%). Therefore, we report for the first time the existence of multiple anthelmintic resistance in gastrointestinal nematodes of sheep in Colombia.
\end{abstract}

Key words: drug resistance, EPG, FECRT, helminth.

\section{INTRODUCTION}

Colombia is considered a livestock country and currently a great interest in sheep farming is occurring (Ospina et al. 2011). The production is mainly focused on meat with a marginal milk industry (González et al. 2011). The population of sheep was estimated at 3.4 million, located mainly

Correspondence to: Marcelo Beltrão Molento

E-mail: molento@ufpr.br in the states of Boyacá, Magdalena, Córdoba, Cundinamarca and Cesar (FAOSTAT 2008). There are many factors favorable to this activity, including the great adaptability of the animals to different climates and environments, and the ease of management (Benavides-Ortiz et al. 2010).

However, there are also many barriers for sheep production. Gastrointestinal parasitism is one of the most important negative economic factors of the small ruminant industry of Colombia 
(Pulido-Medellín et al. 2014). In Colombia there are only a few studies relating small ruminants and parasite infections. Herrera et al. (2013) have reported that Haemonchus contortus is the most prevalent nematode, followed by Trichostrongylus spp., Cooperia spp., Strongyloides spp. and Oesophagostomun spp.. These infections have been described as being responsible for decreasing weight gain, delaying puberty, causing anemia and even death (Ensuncho-Hoyos et al. 2014).

Parasite control is usually carried out with the use of anthelmintics, often indiscriminately and without any epidemiological knowledge (Lara 2013). The use of such suppressive regime added to inaccurate management strategies, contributes to the selection and establishment of parasites that are resistant to the anthelmintics (Almeida et al. 2010). As parasite resistance is an inherited trait, after every generation there may be an increase in individual parasites that would be able to survive drug treatment (Molento 2004). Parasite resistance is an alarming scenario in small ruminants worldwide, but there are no data on the magnitude of parasite resistance in sheep in Colombia. Therefore, the aim of this study was to report the lack of efficacy of the most used anthelmintics against gastrointestinal nematodes of sheep in Colombia.

\section{MATERIALS AND METHODS}

The experiment was performed from January to July of 2011 on four selected sheep Farms, two located in the state of Cundinamarca and two in the state of Valle del Cauca. The drug test protocol was based on Coles et al. (1992). The animals used in this experiment were of mix ages, breeds and were not treated to a minimum of 60 days prior to the study. Initial faecal samples were taken from all animals, to perform parasite egg counts per gram (EPG) according to Gordon and Whitlock (1939).

Groups with a minimum of five animals were treated with Ivermectin (IVM) $1 \% 0.2 \mathrm{mg} /$ kg (Next Mk ${ }^{\circledR}$, Technochemistry, Cali, Colombia),
Albendazole (ABZ) 25\% $5 \mathrm{mg} / \mathrm{kg}$ (Insubenzol ${ }^{\circledR}$, Insuvin, Bogota, Colombia), Fenbendazole (FBZ) $10 \% 5 \mathrm{mg} / \mathrm{kg}$ (Panacur $^{\circledR}$, MSD Salud Animal, Bogota, Colombia), Levamisole (LEV) 10\% $5 \mathrm{mg} /$ kg (Levamisol ${ }^{\circledR}$, Vicar Pharmaceutical, Bogota, Colombia), Moxidectin (MOX) 1\% 0,2 mg/ $\mathrm{kg}$ (Cydectin $^{\circledR}$, Wyeth Inc., Fort Dodge, Bogota, Colombia) and a Control group that received no treatment. The animals were distributed so that the mean EPG was similar between the groups. The animals were weighed before treatment to adjust the correct dose according to the manufacturer recommendations. Although the ideal number of animals would be 6 per group, typical farms in Colombia do not have large numbers of animals and we had to find naturally infected animals with acceptable EPG.

Faecal samples were collected from each animal directly from the rectum, on days: -3 , 0 and 14 after treatment. Samples were placed in individually sealed containers and sent to the Laboratory of Parasitology at the La Salle University, located in Bogota for EPG counts. A stool culture was performed using the method described by van Wyk et al. (2004), identifying 100 larvae per farm. Farmers from each property completed a questionnaire related to treatment with antiparasitic products in order to better describe the situation of parasite control. All procedures were carried out according to the international practices for animal use and care under the control of an internal committee of the University of La Salle, Bogota, Colombia.

Drug efficacy was determined by the faecal egg count reduction test (FECRT) and the percentage reduction was calculated according to Coles et al. (1992). The efficacy of the anthelmintics was analyzed using the RESO 2.01 Analysis Software (Wursthorn and Martin 1990). Data was analyzed considering resistance when the effectiveness of the anthelmintic was lower than $95 \%$ and when the confidence interval was below 90\% (Coles et al. 2006). 


\section{RESULTS AND DISCUSSION}

The results for the efficacy test in each farm are shown on Table I. The FECRT showed that the response to $\mathrm{ABZ}$ and $\mathrm{FBZ}$ in farm 1 was different from the others. According to the RESO software, a suspect of resistance was diagnosed for $\mathrm{ABZ}$ and FBZ in farm 1 because the treatment revealed an egg count reduction just above 95\% (95.5 and $96.5 \%$, respectively) with a confidence interval below $90 \%$ ( 89.6 and $89 \%$, respectively).

TABLE I

Mean of eggs per gram in pretreatment (Mepgpre) and post-treatment (Mepgpos), percentage of faecal egg count reduction (FECR), and lower $95 \%$ confidence interval (CI95\%Low) after anthelmintic treatments in sheep in Colombia.

\begin{tabular}{rcrrrrrr}
\hline \multirow{2}{*}{ Farms } & Product & Animals & Mepgpre & Mepgpost & FECR & CI95\%Low & Variance \\
\hline \multirow{2}{*}{1} & Albendazole & 5 & 1541 & 83 & 96.5 & 89 & $1.07 \mathrm{E}+04$ \\
& Fenbendazole & 5 & 2167 & 108 & 95.5 & 89.6 & $7.42 \mathrm{E}+03$ \\
& Control & 5 & 1620 & 2400 & 0 & & $1.73 \mathrm{E}+06$ \\
\hline \multirow{2}{*}{2} & Fenbendazole & 5 & 1241.7 & 508.3 & 76.5 & 17 & $3.03 \mathrm{E}+05$ \\
& Ivermectin & 5 & 1400 & 150 & 93.1 & 60 & $7.50 \mathrm{E}+04$ \\
& Moxidectin & 5 & 3066.7 & 1100 & 49.2 & -200 & $4.11 \mathrm{E}+06$ \\
& Control & 6 & 1591.7 & 2166.7 & 0 & $5.22 \mathrm{E}+06$ \\
\hline \multirow{3}{*}{3} & Albendazole & 5 & 1875 & 2158.3 & -64.8 & -314 & $3.08 \mathrm{E}+06$ \\
& Fenbendazole & 5 & 991.7 & 533.3 & 59.3 & -128 & $1.05 \mathrm{E}+06$ \\
& Levamisole & 5 & 1741.7 & 1416.7 & -8.1 & -170 & $1,29 \mathrm{E}+06$ \\
& Control & 6 & 620 & 1310 & 0 & $7.94 \mathrm{E}+05$ \\
\hline \multirow{2}{*}{4} & Albendazole & 5 & 2810 & 2180 & 55 & -195 & $1.37 \mathrm{E}+07$ \\
& Fenbendazole & 5 & 3035.7 & 2635.7 & 51.4 & -154 & $1.01 \mathrm{E}+07$ \\
& Ivermectin & 5 & 3750 & 2040 & 67.3 & -132 & $8.75 \mathrm{E}+06$ \\
& Levamisole & 5 & 2250 & 1366.7 & 78.1 & -108 & $7.97 \mathrm{E}+06$ \\
& Control & 5 & 1950 & 2240 & 0 & $9.64 \mathrm{E}+07$ \\
\hline
\end{tabular}

At the other farms, no tested drug showed activity higher than $95 \%$ (ABZ: 55 to $-15.1 \%$; FBZ: 76.6 to $51.4 \%$; IVM: 93.1 to $67.3 \%$; LEV: 78.1 to $-8.1 \%$; and MOX: $49.2 \%$, confirming anthelmintic resistance to all tested products.

In most parts of Latin American countries there are very few restrictions or even none for buying veterinary medicines and farmers are able to purchase them without prescriptions (Molento 2007, Molento et al. 2011). In Colombia this is not different, where the prophylactic use of triclabendazole to control sheep nematodes led to the emergence of Fasciola hepatica resistance detected by the FECRT (Flanagan et al. 2011).

Parasite resistance was determined in all tested farms in Colombia reflecting the same situation found in Uruguay (Bonino and Mederos 2003), Argentina (Caracostantogolo et al. 2006), Peru (Tang-Ploog 2005), Venezuela (Muñoz et al. 2008) and Brazil (Almeida et al. 2010, Cezar et al. 2010, Cruz et al. 2010). Veríssimo et al. (2012) determined resistance to both $\mathrm{ABZ}$ and IVM in $89.3 \%$ of the flocks, and to ABZ and MOX in $82.8 \%$ of the 30 sheep flocks studied in São Paulo, Brazil. SczesnyMoraes et al. (2010) reported resistance to ABZ, closantel (CLO), IVM, LEV, MOX and trichlorfon (TRI) in 11 farms out of 16 in Mato Grosso do Sul, Brazil. Multidrug resistance to ABZ, CLO, IVM and LEV was found in $50 \%$ of the 32 sheep farms in Argentina (Caracostantogolo et al. 2006).

Haemonchus contortus was found in $100 \%$ of the stool culture before the treatment and was 
still predominant (96\%) after anthelmintic use, followed by a small incidence of Trichostrongylus axei (3\%) and Cooperia sp. (1\%).

The fact that $H$. contortus was the only nematode found in the pre-treatment stool culture may be due to its high prevalence throughout South America (Suárez and Busetti 2009, Almeida et al. 2010) including Colombia (Pulido-Medellín et al. 2014). Herrera et al. (2013) analyzed 95 stool samples of small ruminants from five municipalities in the state of Antioquia, Colombia, where $66.3 \%$ (63/95) were positive to $H$. contortus. Martinez (2011), in a survey conducted in Oicata, state of Boyaca, examined 100 samples of sheep from five different farms and in 53\% (53/100) of them, the presence of $H$. contortus was detected. In a study conducted in the state of Cordoba, Colombia, 97.7\% $(170 / 174)$ of the stool samples from sheep were contaminated by gastrointestinal Strongylidae. In $40.83 \%(71 / 174)$ of the coprocultures, the authors observed the presence of the infective stage larvae of Haemonchus sp. (Ensuncho-Hoyos et al. 2014).

The resistance to $H$. contortus to all drug classes have being reported worldwide (Cudekova et al. 2010, Fauvin et al. 2010, Beech et al. 2010). To face this problem, effective new tools need to be developed and implemented for a sustainable control of parasites (Macedo et al. 2012). Colombian research centers are studying new alternative methods, such as nematophagous fungi and herbal medicine (Pino-Benítez and Stashenko 2006, Orozco et al. 2009).

To date, no registered cases of multiple anthelmintic resistance to gastrointestinal nematodes have been reported in sheep in Colombia. Thus, it was very important to study the drug efficacy situation. In the studied regions of the country, there is a predominance of small farms with low levels of investment, which makes the obtained epidemiological information of paramount importance for the local farmers and breeders. We have demonstrated for the first time the existence of multidrug resistant parasites. New studies need to be conducted to further look into other regions of the country and using other compounds.

On the questionnaire, the farmers replied that the anthelmintic use was performed at every 30 day interval in two farms and in between two and three month-intervals. On three farms, the animals were weighted without the use of a scale before the treatment, and only one farmer used the FAMACHA method for partial selective treatment. Only one farmer had some knowledge about parasitic diseases and the drug resistance issue. About the choice of anthelmintic drugs, farmers reported that the choice was based just on the availability of products. Sheep producers should not neglect the present management data because a failure in health management could affect the production of meat and wool (Manfredi et al. 2010). We consider that the strategies for parasite control used by the farmers were responsible for drug failure, as the farmers reported the use of the suppressive strategy for parasite control as a standard sanitary protocol.

The use of questionnaires is an important tool to check how the parasite control is made and to better understand the local epidemiological situation (Nielsen et al. 2006). This practice is used by research groups in an attempt to obtain more accurate worm control data (Čerňanská et al. 2008). In our case, it was determined that in general farmers do not know proper methods of parasite control, nor applied different techniques of sanitary management. In an interview conducted in Rio de Janeiro, Brazil, with 34 sheep producers, although a better technical knowledge about parasitic resistance and its implications was observed, the results were not satisfactory (Cruz et al. 2010). Only by understanding all the epidemiological factors involved in a parasite infection will a correct diagnosis be able to be made and the appropriate set of management strategies be used (Aagard-Hansen et al. 2010).

\section{RESUMO}

Este estudo teve o objetivo de relatar a presença de parasitos resistentes aos fármacos anti-helmínticos 
mais usados em ovinos na Colômbia. Quatro fazendas (denominadas fazendas 1, 2, 3 e 4) foram selecionadas, onde os animais não foram tratados com anti-helmínticos por dois meses antes do experimento. Animais com contagem de ovos por grama de fezes (OPG) acima de 150 e de diferentes idades foram divididos em seis grupos, sendo que cada composto teve pelo menos cinco animais. Os fármacos e dosagens utilizadas foram: ivermectina $1 \%(0,2 \mathrm{mg} / \mathrm{kg})$; albendazol $25 \%(5 \mathrm{mg} /$ $\mathrm{kg}$ ); fembendazol de 10\% (5 mg/kg); levamisol 10\% (5 mg/kg) e moxidectina $1 \%(0,2 \mathrm{mg} / \mathrm{kg})$. A eficácia anti-helmíntica foi determinada pelo teste de redução na contagem de ovos nas fezes (TRCOF), com uma segunda amostragem 14 dias após o tratamento. A eficácia do albendazol e fembendazol na fazenda 1 foi acima de $95 \%$, o que foi diferente das outras fazendas. O TRCOF indicou a presença de resistência a múltiplas drogas nas outras fazendas onde os fármacos testados não mostraram atividade superior a 79\% (albendazol: 0\%-55\%, fenbendazole: 51,4-76,6\%, ivermectina: 67,3-93,1\%, levamisol: 0-78,1\% e moxidectina: 49,264,1\%). Haemonchus contortus foi a espécie predominante (96\%), seguido por uma pequena presença de Trichostrongylus sp. (3\%) e Cooperia sp. (1\%). Portanto, nós relatamos pela primeira vez a existência de resistência anti-helmíntica múltipla em nematóides gastrintestinais de ovinos na Colômbia.

Palavras-chave: resistência anti-helmíntica, OPG, TRCOF, helmintos.

\section{REFERENCES}

AagaARD-Hansen J, Nombela N AND Alvar J. 2010. Population movement: a key factor in the epidemiology of neglected tropical diseases. Trop Med Int Health 15(11): 1281-1288.

ALMEIDA FA, GARCIA KCOD, TORGERSON PR AND AMARANTE AFT. 2010. Multiple resistance to anthelmintics by Haemonchus contortus and Trichostrongylus colubriformis in sheep in Brazil. Parasitol Int 59(4): 622-625.

BEECH R, LEVITT N, CAMBOS M, ZHOU S AND FORRESTER SG. 2010. Association of ion-channel genotype and macrocyclic lactone sensitivity traits in Haemonchus contortus. Mol Biochem Parasitol 171(2): 74-80.

BENAVIDES-ORTIZ E, GUERRA Múrcia N, VALdivia Trujillo V, GutiérRez CAMACHO D, LÓPEZ Rozo M AND SERRANO CONTRERAS AM. 2010. Reporte de caso: pulicosis por Ctenocephalides felis felis en ovinos y caprinos en la sabana de Bogotá, Colombia. Rev Med Vet 19: 123-135.

BONINO J AND MEDEROS A. 2003. Resistencia antihelmíntica en ovinos. Rev Plan Agropec 1: 42-44.

Caracostantogolo J, Castaño R, Cutullé C, Cetrá B, LAMBERTI R AND OLAECHEA F. 2006. Evaluación de la resistencia a los antihelmínticos en rumiantes en Argentina. In: Eddi C and Vargas Terán M (Eds), Resistencia a los Antiparasitarios Internos en Argentina. FAO Producción y Sanidad Animal, Roma, Italia, p. 7-34.

ČERŇANSKÁ D, VÁRADY M, ČUDEKOVÁ P AND ČORBA J. 2008. Worm control practices on sheep farms in the Slovak Republic. Vet Parasitol 154(3): 270-276.

Cezar as, Toscan G, CAMillo G, SANGioni LA, Ribas HO AND VOGEL FSF. 2010. Multiple resistance of gastrointestinal nematodes to nine different drugs in a sheep flock in southern Brazil. Vet Parasitol 173(1): 157160.

Coles GC, Bauer C, Borgsteede FHM, Geerts S, KLEI TR, TAYLOR MA AND WALlER PJ. 1992. World Association for the Advancement of Veterinary Parasitology (W.A.A.V.P.) methods for the detection of anthelmintic resistance in nematodes of veterinary importance. Vet Parasitol 44: 35-44.

Coles GC, JACKSON F, Pomroy WE, Prichard RK, VON SAMSON-HimMELSTJERnA G, Silvestre A, TAYLOR MA AND VERCRUYSSE J. 2006. The detection of anthelmintic resistance in nematodes of veterinary importance. Vet Parasitol 136: 167-185.

Cruz DG, Rocha LO, ARruda SS, Palieraqui JGB, CORDEIRO RC, SANTOS JUNIOR E, MOLENTO MB AND SANTOS CP. 2010. Anthelmintic efficacy and management practices in sheep farms from the state of Rio de Janeiro, Brazil. Vet Parasitol 170(3): 340-343.

CUDEKOVA P, VARADY M, DOLINSKA M AND KONIGOVA A. 2010. Phenotypic and genotypic characterisation of benzimidazole susceptible and resistant isolates of Haemonchus contortus. Vet Parasitol 172: 155-159.

ENSUNCHO-HOYOS C, CASTELLANO-CORONADO A, MAZAÁngulo L, Bustamante-YÁNEZ M AND VERGARAGARAY O. 2014. Prevalencia y grado de infección de nematodos gastrointestinales en ovinos de pelo en pastoreo de cuatro municipios de Córdoba, Colombia. Rev Cient FCV-LUZ 27(5): 414-420.

FAOSTAT - FOOD AND AGRICULTURE ORGANIZATION OF THE UNITED NATIONS. 2008. Roma: FAO. [Cited 2013 jul. 5]. Viewed in: http://faostat.fao.org/.

FAUVIN A, CHARVET C, ISSOUF M, CORTET J, CABARET J AND NEVEU C. 2010. cDNA-AFLP analysis in levamisoleresistant Haemonchus contortus reveals alternative splicing in a nicotinic acetylcholine receptor subunit. Mol and Biochem Parasitol 170(2): 105-107.

FLANAGAN A, EDGAR HWJ, GORDON A, HANNA REB, BRENNAN GP AND FAIRWEATHER I. 2011. Comparison of two assays, a faecal egg count reduction test (FECRT) 
and a coproantigen reduction test (CRT), for the diagnosis of resistance to triclabendazole in Fasciola hepatica in sheep. Vet Parasitol 176(2): 170-176.

GonZÁlez CA, Grajales HA, MANRIQUE C AND TÉLlEZ G. 2011. Information management in livestock production systems: A review of the sheep \& goat case. Rev Fac Med Vet Zootec 58(3): 176-193.

GORDON HML AND WHITLOCK HV. 1939. A new technique for counting nematode eggs in sheep faeces. J Counc Sci Indian Res 12(1): 50-52.

HERRERA L, Ríos LA AND SALAS RZ. 2013. Frecuencia de la infección por nemátodos gastrointestinales en ovinos y caprinos de cinco municipios de Antioquia. Rev MVZ 18(3): 3851-3860.

LARA DM. 2013. Resistencia a los antihelmínticos: origen, desarrollo y control. Rev Cien Tec Agropec 4(1): 55-71.

MACEDO IT, BeVILAQUA CM, OliVEIRA L, CAMURÇAVASCONCELOS AL, MORAIS SM, MACHAD LK AND RIBEIRO WLC. 2012. In vitro activity of Lantana camara, Alpinia zerumbet, Mentha villosa and Tagetes minuta decoctions on Haemonchus contortus eggs and larvae. Vet Parasitol 190(3-4): 504-509.

MANFREDI MT, DI CERBO AR, ZANZANI S AND STRADIOTTO K. 2010. Breeding management in goat farms of Lombardy, northern Italy: Risk factors connected to gastrointestinal parasites. Small Ruminant Res 88(2): 113-118.

MARTINEZ O. 2011. Estudio de prevalencia de parásitos gastrointestinales en ovinos del municipio de OicataBoyaca, Tunja. Universidad Nacional Abierta y a Distancia (UNAD), $64 \mathrm{p}$.

MOLENTO MB. 2004. Resistência de helmintos em ovinos e caprinos. Rev Bras Parasitol Vet 13: 82-87.

MOLENTO MB. 2007. Parasite control strategies. Vet Rec 25: 280-280.

MOLENTO MB, ForTes FS, PONDELEK DAS, BORGES FDA, ChagAs ACDS, TORRES-ACOSTA JFDJ AND GELDHOF P. 2011. Challenges of nematode control in ruminants: focus on Latin America. Vet Parasitol 180(1): 126-132

MuÑoz JA, CUBILlÁN FA, RAMÍREZ R, VALE O, CHACÍN E, SIMOES D AND ATENCIO A. 2008. Eficacia Antihelmíntica de Doramectina 1\%, Ivermectina 1\% y Ricobendazol 15\% frente a Nematodos Gastrointestinales en Ovinos de Pelo. Rev Cient FCV-LUZ 18: 12-16.
NIELSEN MK, MONRAD J AND OLSEN SN. 2006. Prescriptiononly anthelmintics - a questionnaire survey of strategies for surveillance and control of equine strongyles in Denmark. Vet Parasitol 135(1): 47-55.

Orozco M, ÁlVArez V, JimÉnEZ A AND ACUÑA Ó. 2009. In vitro assessment of nematophagus fungi for biological control of gastrointestinal nematodes of ruminants. Rev MVZ 14(3): 1820-1830.

OSPINA Ó, GRAJALES H AND MANRIQUE C. 2011. Gestión del conocimiento: mayor producción y competitividad: Perspectivas para los sistemas de producción ovinocaprinos. Rev Med Vet 22: 95-113.

PINO-BEnÍTEZ N AND STASHENKO E. 2006. Contribución al estudio de la flora medicinal en el departamento del Chocó, Colombia. Fitoterapia 6(1): 125.

Pulido-MEdellín MO, García-Corredor D, DÍAZANAYA A AND ANDRADE-BECERRA R. 2014. Pesquisa de parásitos gastrointestinales en pequeñas explotaciones ovinas del municipio de Toca, Colombia. Rev Salud Ani 36(1): 65-69.

SCZESNY-MORAES EA, BIANCHIN I, Silva KFD, CATTO JB, HONER MR AND PAIVA F. 2010. Resistência antihelmíntica de nematóides gastrintestinais em ovinos, Mato Grosso do Sul. Pesq Vet Bras 30(3): 229-236.

SHALABY HA. 2013. Anthelmintics Resistance; How to Overcome it? Iran J Parasitol 8(1): 18-32.

SUÁREZ VH AND BUSETTI MR. 2009. Health management practices and disease prevalence in dairy sheep systems in Argentina. Pesq Vet Bras 29(11): 931-937.

TANG-PLOOG JF. 2005. Evaluación nematicida y de tolerancia de una formulación al 1\% de ivermectina (Bovimec(C) en ovinos. Agrovetmarket [online]. 2005 [cited 2013 Jul 30]. Avaliable from: http://www.vetermex.com/Pdfs/Trabajos investigacion/ Bovimec_LA.

WURSTHORN L AND MARTIN P. 1990. Reso: faecal egg count reduction test (FECRT) Analysis Program. 2.01. Parkville: CSIRO Animal Health Research Laboratory.

VAN WYK JA, CABARET J AND MICHAEL LM. 2004. Morphological identification of nematode larvae of small ruminants and cattle simplified. Vet Parasitol 119(4): $277-$ 306.

VERÍSSIMO CJ ET AL. 2012. Multidrug and multispecies resistance in sheep flocks from São Paulo state, Brazil. Vet Parasitol 187(1-2): 209-216. 